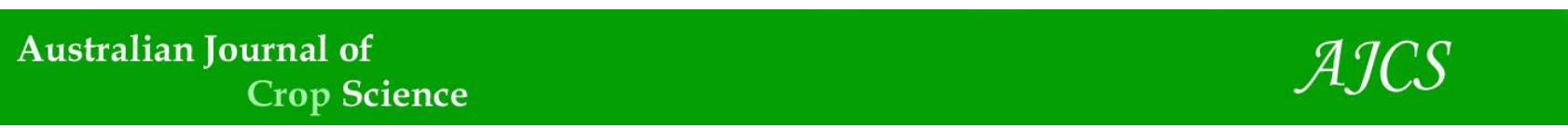

AJCS 15(12):1459-1465 (2021)

ISSN:1835-2707

doi: 10.21475/ajcs.21.15.12.p3322

\title{
Modification of soybean plant architecture through growth regulators and population variation
}

\section{Willian Pelisser da Rosa, Andréia Caverzan, Geraldo Chavarria*}

\author{
Faculty of Agronomy and Veterinary Medicine, Agronomy Post-Graduate Program, University of Passo Fundo, Passo \\ Fundo, Rio Grande do Sul, Brazil
}

\section{*Corresponding autor: geraldochavarria@upf.br}

\begin{abstract}
An important limitation to increased soybean [Glycine max (L.) Merr.] grain yield is excessive plant growth. The use of growth regulators and population adjustment is imperative for the management of soybean. This study aimed to evaluate whether lactofen, used as a growth regulator, and a reduction in plant population affected the architecture of soybean and increased its production efficiency. The study was carried out under field conditions during the 2017-2018 and 2018-2019 seasons. The experimental design was in completely randomised blocks with five treatments and five replications: T1 (control), T2 (application of $140 \mathrm{~g}$ a.i. ha ${ }^{-1}$ of lactofen at phenological stage V3), T3 (application of $140 \mathrm{~g}$ a.i. ha ${ }^{-1}$ of lactofen at phenological stage V6), T4 (plant population 20\% lower than recommended) and T5 (plant population $40 \%$ lower than recommended). The plant height, the number of nodes, the number of branches, stem diameter, and the internode distance were affected by lactofen application at stage V3. Lactofen use at stage V3 also increased the coverage percentage and the number of droplets per square centimetre of phytosanitary products. The interception of solar radiation was higher with lactofen application at stage V3 and that treatment provided the highest yield. Therefore, the use of lactofen as a growth regulator improves soybean grain yield. A reduction in plant population had the greatest effect on grain number and weight. Plant density should be maintained as recommended to avoid a decrease in grain yield.
\end{abstract}

Keywords: Glycine max L.; growth management; self-shading, solar radiation; grain yield Abbreviations: LAI - leaf area index, PAR - photosynthetically active solar radiation

\section{Introduction}

Among many factors that decrease soybean [Glycine $\max$ (L.) Merrill] production is excessive plant growth, which most often occurs in years of high precipitation and lower light availability (Martins et al., 1999). Self-shading mainly affects the lower layers of plants, causing the premature falling of leaves and the death of flowers and pods. Along with this, it is difficult to control diseases owing to the formation of an ideal microclimate for their development and the fact that reaching the target with phytosanitary products is difficult (Chavarria et al., 2017).

In this context, some studies are being developed to investigate the use of growth regulators to reduce the excessive growth of soybean plants (Buzzello et al., 2013) and decrease the plant population (Ferreira et al., 2018; Menegaz et al., 2018). Depending upon the plant population in the field, the interception of photosynthetically active radiation varies. Solar radiation is involved in the production of photoassimilates and the maintenance of photosynthetic activity (Chavarria et al., 2017).

Lactofen (2-ethoxy-1-methyl-2-oxoethyl 5-[2-chloro4(trifluoromethyl)phenoxy]-2-nitrobenzoate) is a product that can potentially be used as a growth regulator in soybean. It is a selective-contact herbicide, an inhibitor of the protoporphyrinogen oxidase enzyme and belongs to the diphenyl ether group (Gallon et al., 2016). Thus, lactofen induces cell death (Graham, 2005) and causes phytotoxicity in plants after its application (Huzar-Novakowiski, 2017), which causes growth inhibition, breaking of apical dominance, growth of lateral branches and the creation of shorter plants (Gallon et al., 2016).

This study tested the hypothesis that the use of lactofen as a growth regulator and a reduction in the soybean population, which has the characteristic of excessive growth and height, tend to improve the photosynthetic activity, favouring the application of phytosanitary products and hence increasing grain yield, especially in the lower layers. The aim was to evaluate whether lactofen, used as a growth regulator, and a reduction in plant population interfere with the architecture and increase the production efficiency of soybean.

\section{Results and discussion}

\section{Plant growth and development}

The plant heights at phenological stage R1 was significantly different in the two years of study. The control presented the highest values: 49.0 and $61.9 \mathrm{~cm}$ in the first and second years, respectively. Lactofen application at phenological stage V3 showed the lowest values $(44.2$ and $52.3 \mathrm{~cm}$, respectively, Table 1). Souza et al. (2002) found similar results when applying lactofen to soybean plants, reducing the height by $5.7-10.5 \%$. In addition, after a week of 
lactofen treatment at the R1 stage, the soybean plants were shorter and their leaves were distorted in shape (HuzarNovakowiski, 2017).

The influence of treatments decreased when height was evaluated at phenological stage R5.2, particularly in the first year of study (Table 1 ). These results followed those found by Campos et al. (2008), who observed that soybean plants submitted to mepiquat chloride application did not reduce the plant height measured 105 days after emergence.

In the second year, plants that received lactofen application and plant population had a lower height; the difference was smaller in comparison to the evaluation at phenological stage R1 (Table 1). Similar results were found by Cato and Castro (2006), who found a reduction caused by 2,3,5triiodobenzoic acid treatment of up to $54 \%$ in the heights of soybean plants in an evaluation carried out at the beginning of grain filling. Plants require more light during the flowering period in order to perform photosynthesis on a large scale and express their maximum production potential (Liu et al., 2010). In this sense, a reduction in height at this stage, as presented in this study, is interesting and benefits grain yield.

The treatment with a $40 \%$ population reduction had a higher leaf area index (LAI) than the others in the second year of study, with a value of 7.2, while the mean was 5.1 for other treatments (Table 1). Thus, although treatments affected plant height, they did not reduce the photosynthetic area. According to Liu et al. (2008), the best efficiency in light interception by the canopy is obtained with an LAI between 3.5 and 4 in soybean crops, with no issues regarding flaws in crop closure or excessive leaf shading. The results found in this study demonstrate that all treatments had a higher LAI. A high LAl could negatively affect grain yield because an LAI greater than 5 causes self-shading and high energy expenditure. Therefore, an LAI between 4 and 5 is the most appropriate for soybean cultivars. However, this may vary among genotypes, crop management styles, phenological stages and plant leaf features (Müller et al., 2017).

The treatment with a $40 \%$ reduction in plant population had a significantly higher number of nodes per plant in the first year, with a value of 58.9, while the control showed the lowest value, of 28.4 (Table 1). A significant difference for node number was observed when the control was compared to treatments with lactofen application at phenological stages V3 and V6, with a value $27 \%$ lower in the control (Table 1). The same tendency was found for the second year of cultivation; the treatment with a $40 \%$ reduction in plant population had 63.7 nodes per plant, while the control had 34.6 nodes per plant. A difference of $7 \%$ was observed between the control and treatments with lactofen application at phenological stages V3 and V6 (Table 1). The reduced plant population strongly influenced this variable, with a significant increase in the number of nodes per plant. This occurred because of the higher availability of space for plant growth, which allowed more branching and thus an increase in the number of nodes (Bellaloui et al., 2014). Lactofen application occurred at the time when plants were developing nodes. However, even plants undergoing stress caused by lactofen showed an increased number of nodes. Soybean plants must reach a minimum number of nodes per plant to achieve high grain yields (15 to 20), as reproductive structures are formed in these organs (Bahry et al., 2013).

The number of branches was influenced by treatments, primarily those with a reduction in plant population, with a mean increase of two branches per plant in comparison to other treatments (Table 1). This is in accordance because soybean plants can compensate for low planting populations by increasing branches, nodes and ultimately, pods (Chavarria et al., 2017). The hypothesis was that the use of lactofen led to a break in apical dominance and consequently an increase in the branches per plant, in comparison to the control. However, this occurred only in the first year of study, with an increase of almost two branches per plant (Table 1). The data found are in agreement with the results of Campos et al. (2009), Dario et al. (2005) and Heiffing (2006), who applied different growth regulators to soybean crops and did not find any influence on the number of branches.

The results of both years showed that the highest influence on stem diameter was observed in treatments with a reduction in plant population, with a mean increase of $2 \mathrm{~mm}$ in diameter in comparison to other treatments (Table 1). Lactofen application had little influence on this variable, which differed from the results of Souza et al. (2013), who found a significant reduction in stem diameter in soybean plants treated with different growth regulators.

The distance between the third and fourth internodes and the distance between the sixth and seventh internodes were influenced by treatments in both years, and the control in all cases presented a higher distance of internodes, with a mean $2 \mathrm{~mm}$ increase (Table 1). These internodes are the most important structures related to the lodging of plants. Plants with lower internode lengths are more resistant to lodging and tend to have smaller heights (Liu et al., 2010). Lactofen application decreased internode distance, which can be explained by the inhibition of plant growth after application. Lactofen has the characteristic of causing phytotoxicity in plants, thus growth is inhibited for approximately 20 days (Wichert and Talbert, 1993), leading to a shortening of internodes.

\section{Photosynthetically active solar radiation}

The use of lactofen and the reduction in plant population influenced photosynthetically active solar radiation (PAR) interception in the upper and lower strata of plants, but the strongest influence occurred in the lower layer (Table 2). The use of lactofen at phenological stage V3 in the first year of study showed a $25 \%$ increase in PAR interception in comparison to the control, but the treatment with a $40 \%$ reduction in population had the best result in the second year, with an increase of $10 \%$ (Table 2). This increase in the light interception by the plant canopy, as well as that of droplet deposition, is related to the modification in plant architecture, which became more efficient at light interception (Chavarria et al., 2017).

Clearly, the architectural characteristics of plants contribute to better performance. Müller et al. (2018) demonstrated that soybean plants with low height, low branch number and low LAl could achieve greater product deposition in the middle and lower canopy layers. In addition, the amounts of photosynthetically active radiation in different cultivars can vary in the canopy layers (Müller et al., 2018). Furthermore, photosynthetically active radiation interception is variable depending on plant population in the field, the environmental conditions and plant genotype (Chavarria et al., 2017).

Droplet deposition

In general, the treatment that received lactofen application at phenological stage V3 had the best results for the percentage of covered area and the number of droplets per 
Table 1. Vegetative growth of soybean plants of the cultivar 'TMG 7062 IPRO' subjected to lactofen application and plantpopulation variation.

\begin{tabular}{|c|c|c|c|c|c|c|c|c|}
\hline \multicolumn{9}{|c|}{ 2017-2018 Crop season } \\
\hline Treatment & $\begin{array}{l}\text { Plant } \\
\text { height } \\
\text { R1 }(\mathrm{cm})\end{array}$ & $\begin{array}{c}\text { Plant } \\
\text { height } \\
\text { R5.2 }(\mathrm{cm})\end{array}$ & $\begin{array}{c}\text { LAI } \\
\left(\mathrm{m}^{2} / \mathrm{m}^{2}\right)\end{array}$ & $\begin{array}{c}\text { Number of } \\
\text { nodes } \\
\left(n^{\circ} \mathrm{pl}^{-1}\right)\end{array}$ & $\begin{array}{c}\text { Number of } \\
\text { branches } \\
\left(\mathrm{n}^{\circ} \mathrm{pl}^{-1}\right)\end{array}$ & $\begin{array}{c}\text { Stem } \\
\text { diameter } \\
(\mathrm{mm})\end{array}$ & $\begin{array}{c}\text { Internode } \\
\text { lenght } \\
\text { 3/4 }(\mathrm{mm})\end{array}$ & $\begin{array}{c}\text { Internode } \\
\text { lenght } \\
\text { 6응 }(\mathrm{mm})\end{array}$ \\
\hline $\mathrm{T} 1$ & $49.0 a^{*}$ & $108.7 \mathrm{a}^{*}$ & $4.7^{\mathrm{ns}}$ & $28.4 \mathrm{~d}^{*}$ & $1.9 \mathrm{~d}^{*}$ & $8.4 \mathrm{~d}^{*} \mathrm{a}$ & $17.6 a^{*} a$ & $34.7 a^{*}$ \\
\hline $\mathrm{T} 2$ & $44.2 c^{*}$ & $108.5 a^{*}$ & $5.0^{\mathrm{ns}}$ & $40.0 c^{*}$ & $3.1 c^{*}$ & $9.9 \mathrm{bc}^{*}$ & $15.9 \mathrm{ba}^{*}$ & $27.4 c^{*}$ \\
\hline T3 & $45.6 b^{*}$ & $108.7 a^{*}$ & $4.9^{\text {ns }}$ & $38.9 c^{*}$ & $3.3 c^{*}$ & $9.7 \mathrm{ca}^{*}$ & $16.9 a b^{*}$ & $30.2 b^{*}$ \\
\hline T4 & $46.2 b^{*}$ & $107.4 a^{*}$ & $5.1^{\text {ns }}$ & $44.5 b^{*}$ & $3.6 b^{*}$ & $10.2 \mathrm{ba}^{*}$ & $15.7 \mathrm{ba}^{*}$ & $25.5 c^{*}$ \\
\hline T5 & $45.9 b^{*}$ & $104.3 b^{*}$ & $5.1^{\mathrm{ns}}$ & $58.9 a^{*}$ & $4.8 a^{*}$ & $11.4 \mathrm{aa}^{*}$ & $15.5 \mathrm{ba}^{*}$ & $25.4 c^{*}$ \\
\hline C.V. (\%) & 0.9 & 1.4 & $6.2^{\mathrm{ns}}$ & 2.4 & 5.5 & 3.9 & 5.2 & 5.6 \\
\hline \multicolumn{9}{|c|}{ 2018-2019 Crop season } \\
\hline Treatment & $\begin{array}{c}\text { Plant } \\
\text { height } \\
\text { R1 }(\mathrm{cm})\end{array}$ & $\begin{array}{c}\text { Plant } \\
\text { height } \\
\mathrm{R} 5.2(\mathrm{~cm})\end{array}$ & $\begin{array}{c}\text { LAI } \\
\left(\mathrm{m}^{2} / \mathrm{m}^{2}\right)\end{array}$ & $\begin{array}{c}\text { Number of } \\
\text { nodes } \\
\left(n^{\circ} \mathrm{pl}^{-1}\right)\end{array}$ & $\begin{array}{c}\text { Number of } \\
\text { branches } \\
\left(\mathrm{n}^{0} \mathrm{pl}^{-1}\right)\end{array}$ & $\begin{array}{c}\text { Stem } \\
\text { diameter } \\
(\mathrm{mm})\end{array}$ & $\begin{array}{c}\text { Internode } \\
\text { lenght } \\
3 \circ / 4 \circ(\mathrm{mm})\end{array}$ & $\begin{array}{c}\text { Internode } \\
\text { lenght } \\
\text { 6응 }(\mathrm{mm})\end{array}$ \\
\hline T1 & $61.9 a^{*} a$ & $119.8 a^{*} a$ & $5.8 \mathrm{~b}$ & $34.6 \mathrm{~d}^{*}$ & $3.4 c^{*}$ & $11.5 c^{*}$ & $18.6 \mathrm{a}^{*}$ & $31.6 a^{*}$ \\
\hline $\mathrm{T} 2$ & $52.3 \mathrm{da}^{*}$ & $115.6 \mathrm{bc}^{*}$ & $5.7 \mathrm{~b}$ & $36.6 c^{*}$ & $3.20 c^{*}$ & $10.4 \mathrm{~d}^{*}$ & $17.6 b^{*}$ & $30.6 b^{*}$ \\
\hline T3 & $54.3 \mathrm{ca}^{*}$ & $117.5 b^{*} a$ & $5.6 \mathrm{~b}$ & $37.6 c^{*}$ & $3.1 c^{*}$ & $11.6 c^{*}$ & $16.6 b^{*}$ & $30.7 b^{*}$ \\
\hline T4 & $56.3 \mathrm{ba}^{*}$ & $114.2 c^{*} a$ & $5.9 \mathrm{~b}$ & $48.2 b^{*}$ & $4.7 b^{*}$ & $12.0 b^{*}$ & $16.8 b^{*}$ & $29.2 c^{*}$ \\
\hline T5 & $53.0 \mathrm{~cd}^{*}$ & $113.8 \mathrm{c}^{*} \mathrm{a}$ & $7.2 \mathrm{a}$ & $63.8 a^{*}$ & $5.4 a^{*}$ & $13.6 a^{*}$ & $14.8 \mathrm{~d}^{*}$ & $24.4 \mathrm{~d}^{*}$ \\
\hline C.V. (\%) & 1.6 & 0.9 & 4.3 & 2.3 & 5.9 & 2.5 & 3.9 & 1.4 \\
\hline
\end{tabular}

Means followed by lowercase letters in the same column do not differ from each other, according to the Duncan test at 5\% probability of error. ns: Not significant. CV: Coefficient of variation. LAl: Leaf area index. R1 - an open flower on any stem node. R5.2 - legumes in the last four stem nodes, with $25 \%$ of maximum graining. Treatments: T1 - control, T2 - application of $140 \mathrm{~g}$ a.i. ha ${ }^{-1}$ of lactofen at phenological stage V3, T3 - application of $140 \mathrm{~g}$ a.i. ha ${ }^{-1}$ of lactofen at phenological stage V6, T4 - plant population $20 \%$ lower than that recommended, and T5 - plant population $40 \%$ lower than that recommended. ${ }^{*}$ Mean per plant.

(A)

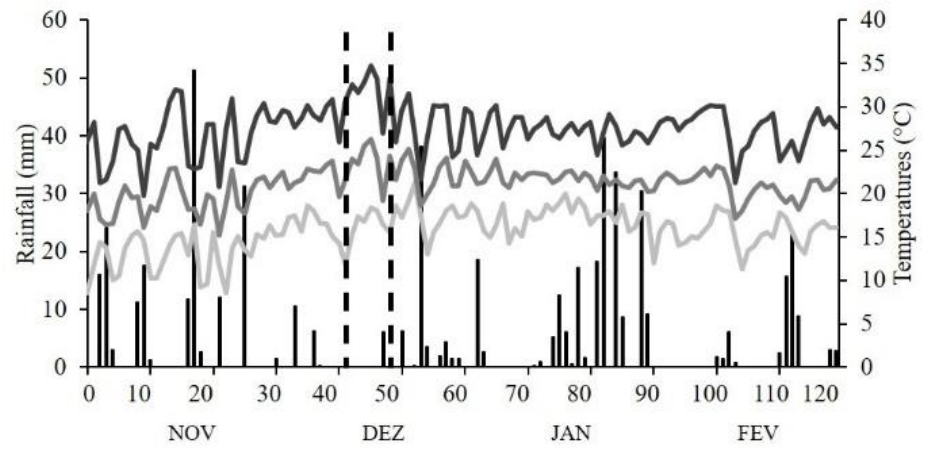

— Rainfall _ - - Lactofen application — Maximum TM — Minimum TM — Mean TM

(B)

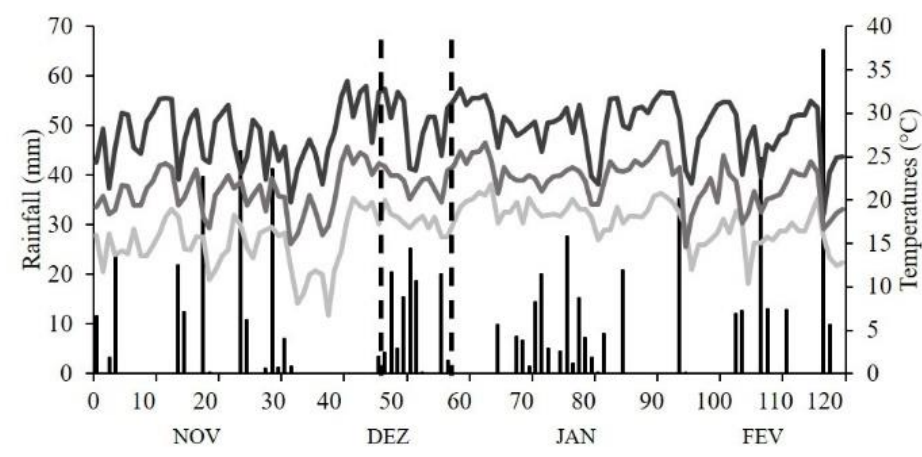

- Rainfall - - Lactofen application

— Maximum TM

Minimum TM

Mean TM

Figure 1. Rainfall and temperatures (maximum, minimum and mean temperature) during the crop cycle; lactofen application at phenological stages V3 and V6; (A) 2017-2018 crop season and (B) 2018-2019 crop season. Source: Embrapa Trigo (2018; 2019). 
Table 2. Droplet deposition and interception of photosynthetically active solar radiation by strata in soybean plants of the cultivar 'TMG 7062 IPRO', subjected to lactofen application and plant-population variation.

\begin{tabular}{|c|c|c|c|c|c|c|c|c|}
\hline \multicolumn{9}{|c|}{ 2017-2018 Crop season } \\
\hline \multirow[t]{2}{*}{ Treatment } & \multicolumn{2}{|c|}{ PAR } & \multicolumn{2}{|c|}{ Upper layer } & \multicolumn{2}{|c|}{ Middle layer } & \multicolumn{2}{|c|}{ Lower layer } \\
\hline & $\begin{array}{l}\text { Upper layer } \\
\left(\mu \mathrm{mol} \cdot \mathrm{m}^{-2} \cdot \mathrm{s}^{-1}\right)\end{array}$ & $\begin{array}{l}\text { Lower layer } \\
\left(\mu \mathrm{mol} . \mathrm{m}^{-2} \cdot \mathrm{s}^{-1}\right)\end{array}$ & $\begin{array}{l}\text { Coverage } \\
\text { area (\%) }\end{array}$ & $\begin{array}{c}\text { Number of } \\
\text { impacts }\left(\mathrm{cm}^{2}\right)\end{array}$ & $\begin{array}{l}\text { Coverage } \\
\text { area (\%) }\end{array}$ & $\begin{array}{c}\text { Number of } \\
\text { impacts }\left(\mathrm{cm}^{2}\right)\end{array}$ & $\begin{array}{l}\text { Coverage } \\
\text { area (\%) }\end{array}$ & $\begin{array}{c}\text { Number of } \\
\text { impacts }\left(\mathrm{cm}^{2}\right)\end{array}$ \\
\hline $\mathrm{T} 1$ & 1520.8 ba & $70.0 \mathrm{c}$ & $22.9 \mathrm{da}$ & $314.0 \mathrm{~b}$ & $11.9 \mathrm{~b}$ & $116.4 \mathrm{c}$ & $3.0 c$ & $41.1 \mathrm{c}$ \\
\hline $\mathrm{T} 2$ & 1607.4 aa & $93.0 \mathrm{a}$ & $32.1 \mathrm{ab}$ & 407.9 a & $24.1 \mathrm{a}$ & $184.0 \mathrm{a}$ & $6.4 \mathrm{a}$ & $63.9 \mathrm{~b}$ \\
\hline T3 & $1563.0 \mathrm{ab}$ & $79.4 \mathrm{~b}$ & $30.3 \mathrm{bc}$ & $313.4 \mathrm{~b}$ & $10.4 \mathrm{~b}$ & $84.6 \mathrm{e}$ & $1.8 \mathrm{~d}$ & $40.9 c$ \\
\hline T4 & $1568.6 \mathrm{ab}$ & $68.4 \mathrm{c}$ & $29.2 \mathrm{ca}$ & $317.8 \mathrm{~b}$ & $9.5 \mathrm{~b}$ & $92.6 \mathrm{~d}$ & $1.7 \mathrm{~d}$ & $39.7 \mathrm{c}$ \\
\hline T5 & $1580.2 \mathrm{ab}$ & $69.2 c$ & 33.8 aa & $326.4 \mathrm{~b}$ & $11.6 \mathrm{~b}$ & $138.6 \mathrm{~b}$ & $4.8 b$ & $69.6 \mathrm{a}$ \\
\hline C.V. (\%) & 2.8 & 3.4 & 6.7 & 3.4 & 13.7 & 3.7 & 19.3 & 7.2 \\
\hline \multicolumn{9}{|c|}{ 2018-2019 Crop season } \\
\hline \multirow[t]{2}{*}{ Treatment } & \multicolumn{2}{|c|}{ PAR } & \multicolumn{2}{|c|}{ Upper layer } & \multicolumn{2}{|c|}{ Middle layer } & \multicolumn{2}{|c|}{ Lower layer } \\
\hline & $\begin{array}{l}\text { Upper layer } \\
\left(\mu \mathrm{mol} \cdot \mathrm{m}^{-2} \cdot \mathrm{s}^{-1}\right)\end{array}$ & $\begin{array}{l}\text { Lower layer } \\
\left(\mu \mathrm{mol} \cdot \mathrm{m}^{-2} \cdot \mathrm{s}^{-1}\right)\end{array}$ & $\begin{array}{l}\text { Coverage } \\
\text { area }(\%)\end{array}$ & $\begin{array}{c}\text { Number of } \\
\text { impacts }\left(\mathrm{cm}^{2}\right)\end{array}$ & $\begin{array}{l}\text { Coverage } \\
\text { area (\%) }\end{array}$ & $\begin{array}{c}\text { Number of } \\
\text { impacts }\left(\mathrm{cm}^{2}\right)\end{array}$ & $\begin{array}{l}\text { Coverage } \\
\text { area (\%) }\end{array}$ & $\begin{array}{c}\text { Number of } \\
\text { impacts }\left(\mathrm{cm}^{2}\right)\end{array}$ \\
\hline $\mathrm{T} 1$ & $1482.2 \mathrm{c}$ & $170.8 \mathrm{ca}$ & $21.3 \mathrm{~d}$ & $283.3 \mathrm{c}$ & $9.0 \mathrm{c}$ & $111.6 \mathrm{c}$ & $1.7 \mathrm{c}$ & $36.5 \mathrm{c}$ \\
\hline $\mathrm{T} 2$ & $1541.2 \mathrm{a}$ & 179.2 ba & $31.5 \mathrm{a}$ & 403.9 a & $21.5 \mathrm{a}$ & $177.4 \mathrm{a}$ & $5.7 \mathrm{a}$ & $79.5 \mathrm{a}$ \\
\hline T3 & 1492.4 c & $132.4 \mathrm{da}$ & $28.7 \mathrm{~b}$ & $318.1 \mathrm{~b}$ & $4.8 \mathrm{e}$ & 78.3 e & $1.3 \mathrm{c}$ & $17.2 \mathrm{e}$ \\
\hline T4 & $1503.4 \mathrm{~b}$ & $184.4 \mathrm{ab}$ & $24.8 \mathrm{c}$ & $324.3 \mathrm{~b}$ & $6.7 \mathrm{~d}$ & $89.6 \mathrm{~d}$ & $1.3 \mathrm{c}$ & $20.1 \mathrm{~d}$ \\
\hline T5 & $1485.4 \mathrm{c}$ & 189.6 aа & $31.1 \mathrm{a}$ & $321.8 \mathrm{~b}$ & $10.2 \mathrm{~b}$ & $136.0 \mathrm{~b}$ & $4.8 b$ & $65.4 \mathrm{~b}$ \\
\hline C.V. (\%) & 0.5 & 3.6 & 2.8 & 2.4 & 6.0 & 5.2 & 10.4 & 3.8 \\
\hline
\end{tabular}

Table 3. Number of grains, grain mass and final yield of soybean grains of the cultivar 'TMG 7062 IPRO' subjected to lactofen application and plant-population variation

\begin{tabular}{|c|c|c|c|c|c|c|c|c|}
\hline \multicolumn{9}{|c|}{ 2017-2018 Crop season } \\
\hline \multirow[t]{2}{*}{ Treatment } & \multicolumn{3}{|c|}{ Number of grains $\left(\mathrm{n}^{0} \mathrm{pl}^{-1}\right)$} & \multicolumn{3}{|c|}{ Grain mass (g) } & \multirow[t]{2}{*}{ TGW (g) } & \multirow{2}{*}{$\begin{array}{c}\text { Grain yield } \\
\left(\mathrm{kg} \mathrm{ha}^{-1}\right)\end{array}$} \\
\hline & Upper layer & Middle layer & Lower layer & Upper layer & Middle layer & Lower layer & & \\
\hline T1 & $49.0 c^{*}$ & $55.3 e^{*}$ & $19.2 \mathrm{bc}^{*}$ & $8.6 c^{*}$ & $12.1 c^{*}$ & $4.2 \mathrm{~cd}^{*}$ & $190.7 \mathrm{ca}$ & 3617 a \\
\hline $\mathrm{T} 2$ & $52.0 c^{*}$ & $63.6 c^{*}$ & $19.7 b c^{*}$ & $9.3 c^{*}$ & $15.6 b^{*}$ & $5.1 \mathrm{~b}^{*} \mathrm{a}$ & 205.6 aa & $3634 \mathrm{a}$ \\
\hline T3 & $47.9 c^{*}$ & $60.2 \mathrm{~d}^{*}$ & $18.2 \mathrm{c}^{*} \mathrm{a}$ & $8.5 c^{*}$ & $12.1 c^{*}$ & $4.0 \mathrm{~d}^{*} \mathrm{a}$ & $187.7 \mathrm{~cd}$ & 3577 a \\
\hline $\mathrm{T} 4$ & $60.4 b^{*}$ & $82.3 b^{*}$ & $20.9 \mathrm{~b}^{*} \mathrm{a}$ & $11.2 c^{*}$ & $15.5 b^{*}$ & $4.6 \mathrm{c}^{*} \mathrm{a}$ & $196.9 \mathrm{ba}$ & $3558 \mathrm{~b}$ \\
\hline T5 & $75.4 a^{*}$ & $102.4 \mathrm{a}^{*}$ & $27.8 a^{*} a$ & $14.5 \mathrm{a}^{*}$ & $20.8 a^{*}$ & $7.2 a^{*} a$ & $185.7 \mathrm{da}$ & $3422 b$ \\
\hline C.V. (\%) & 5.2 & 3.2 & 7.1 & 8.2 & 6.1 & 7.0 & 1.2 & 1.6 \\
\hline \multicolumn{9}{|c|}{ 2018-2019 Crop season } \\
\hline Treatment & \multicolumn{3}{|c|}{ Number of grains $\left(\mathrm{n}^{0} \mathrm{pl}^{-1}\right)$} & \multicolumn{3}{|c|}{ Grain mass $(\mathrm{g})$} & \multirow[t]{2}{*}{ TGW (g) } & \multirow{2}{*}{$\begin{array}{c}\text { Grain yield } \\
\left(\mathrm{kg} \mathrm{ha}^{-1}\right)\end{array}$} \\
\hline & Upper layer & Middle layer & Lower layer & Upper layer & Middle layer & Lower layer & & \\
\hline T1 & $47.6 c^{*}$ & $58.8 \mathrm{c}^{*}$ & $16.4 \mathrm{~d}^{*}$ & $9.6 \mathrm{~d}^{*} \mathrm{a}$ & $13.0 c^{*}$ & $3.6 \mathrm{~d}^{*}$ & $212.3 \mathrm{a}$ & 4532 b \\
\hline $\mathrm{T} 2$ & $45.5 c^{*}$ & $56.9 c^{*}$ & $18.2 c^{*}$ & $10.5 \mathrm{c}^{*} \mathrm{a}$ & $13.1 c^{*}$ & $4.1 \mathrm{c}^{*}$ & $214.4 \mathrm{a}$ & $4634 \mathrm{a}$ \\
\hline T3 & $48.1 c^{*}$ & $53.1 \mathrm{~d}^{*}$ & $15.6 \mathrm{~d}^{*}$ & $9.8 \mathrm{~cd}^{*}$ & $11.6 \mathrm{~d}^{*}$ & $3.6 \mathrm{~d}^{*}$ & $208.6 b$ & $4551 \mathrm{~b}$ \\
\hline T4 & $56.8 b^{*}$ & $74.2 b^{*}$ & $23.3 b^{*}$ & $11.2 \mathrm{~b}^{*} \mathrm{a}$ & $16.2 b^{*}$ & $5.1 b^{*}$ & $213.1 \mathrm{a}$ & $4547 \mathrm{~b}$ \\
\hline T5 & $64.2 a^{*}$ & $87.0 a^{*}$ & $28.9 a^{*}$ & $13.2 \mathrm{a}^{*} \mathrm{a}$ & $18.9 a^{*}$ & $6.2 a^{*}$ & $214.7 \mathrm{a}$ & $4135 \mathrm{c}$ \\
\hline C.V. (\%) & 5.4 & 3.9 & 5.2 & 4.7 & 4.1 & 6.9 & 0.8 & 1.2 \\
\hline
\end{tabular}

Means followed by lowercase letters in the same column do not differ from each other, according to the Duncan test at $5 \%$ probability of error. ns: Not significant. CV: Coefficient of variation. TGW: thousand-grain weight. Treatments: T1 - control, T2 - application of $140 \mathrm{~g}$ a.i. ha ${ }^{-1}$ of lactofen at phenological stage V3, T3 - application of $140 \mathrm{~g}$ a.i. ha ${ }^{-1}$ of lactofen at phenological stage V6, T4 - plant population $20 \%$ lower than that recommended, and T5 - plant population $40 \%$ lower than that recommended. *Mean per plant.

square centimetre for the three plant layers in both years of study (Table 2). The higher the percentage of area covered with spraying, the greater the power to control diseases that damage crops (Chavarria et al., 2017). These treatments modified plant architecture and provided a higher droplet deposition of phytosanitary products on leaves via spraying, primarily in the middle and lower layers. These variables increased considerably when plants had their architecture modified by the use of lactofen. The means of both years showed increases of 30,51 and 61\% in the covered area in the upper, middle and lower layers, respectively, in comparison to the control. Soybean cultivars vary in architecture, which influences the deposition of droplets in the plant strata. The droplet deposition in the plant is influenced by architectural characters such as stature, the number of branches and the size, number, format and orientation of the leaves (Chavarria et al., 2017). For the number of impacts per square centimetre, the increase follows the same trend, i.e. 26,37 and $44 \%$, respectively (Table 2). These results show that the lower third presented the highest increase, indicating that it was the area most difficult for phytosanitary products to reach. In addition to increasing the droplet deposition of phytosanitary products on the lower layers of soybean plants, the stimulation of secondary metabolism by lactofen could also affect the efficiency of disease control (Cheng et al., 2011). 


\section{Grain yield components}

Yield components were positively influenced by treatments that reduced plant population, with a $30 \%$ increase in the number and weight of grains per plant layer in comparison to other treatments. A reduced plant population contributes to a larger grain yield through the increase in the number of fertile legumes and higher grain weight due to a decrease in intraspecific competition (Chavarria et al., 2017). The use of lactofen at phenological stage V3 presented an increase in grain weight of $20 \%$ for the lower layer and $10 \%$ for the middle layer in comparison to the control (Table 3 ). The higher grain yield in the lower plant layer that received lactofen application is potentially because of a break in apical dominance and a reduction in height. Therefore, plants that are more compact better intercept PAR in the lower layer, increasing net carbon assimilation. The increased photosynthetic activity efficiency in the lower layer leads to plants being more productive (Müller et al., 2017). Although a reduction in plant population has a positive effect on yield components, the final grain yield was negatively affected. In this case, the higher number and weight of grains were not sufficient to compensate for the lack of plants per square metre. Thus, lactofen application at phenological stage $\mathrm{V} 3$ in the second year of the study was more effective and resulted in a higher final yield in comparison to the control and treatments that reduced the plant population (Table 3 ). In the second year, the rain volume was high at the stages of lactofen application, so the plants had faster recovery from the phytotoxicity generated by lactofen and consequently produced a greater number and mass of grains, culminating in a greater grain yield. On the other hand, previous studies on lactofen application at the early vegetative stage found that the use of growth regulators did not affect total yield components (Gregg et al., 2015; Mangialardi et al., 2016; Orlowski et al., 2016a, b).

\section{Materials and methods}

\section{Plant materials}

The cultivar 'TMG 7062 IPRO' was used in both years of the experiment. It is an early cultivar, with semi-determinate habit growth, maturation group 6.2, large height and high branching index. Due to the characteristics of excessive growth and height, high biomass production and a long cycle, 'TMG 7062 IPRO' was used in this study. Seeds were obtained directly from the breeder and presented germination rates above $90 \%$ and vigour at $85 \%$. The growth regulator lactofen is a selective-contact herbicide inhibitor of the protoporphyrinogen oxidase enzyme, belonging to the diphenyl ether group and was used at a concentration of 240 g a.i. $L^{-1}$.

\section{Site description}

This study was conducted under field conditions in 20172018 (sown on 12 November and harvested on 20 March) and 2018-2019 (sown on 21 November and harvested on 28 March) seasons in the municipality of Passo Fundo, Rio Grande do Sul, Brazil. The area is located at an altitude of $687 \mathrm{~m}$, latitude $28^{\circ} 23^{\prime} \mathrm{S}$ and longitude $52^{\circ} 38^{\prime} \mathrm{W}$. The site is located in a region with a humid, subtropical climate. The soil was classified as a humid dystrophic red latosol (Streck et al., 2008).

\section{Experimental design}

The experiments were conducted in completely randomised blocks, comprising five treatments and five replications: T1 (control), T2 (application of $140 \mathrm{~g}$ a.i. ha ${ }^{-1}$ of lactofen at phenological stage V3), T3 (application of $140 \mathrm{~g}$ a.i. ha ${ }^{-1}$ of lactofen at phenological stage V6), T4 (plant population 20\% lower than recommended, 16 plants per square metre) and T5 (plant population 40\% lower than recommended, 12 plants per square metre). The lactofen application of $140 \mathrm{~g}$ a.i. ha ${ }^{-1}$ was based on a study by Gallon et al. (2016), and the lactofen application of $240 \mathrm{~g}$ a.i. ha ${ }^{-1}$ was based on a study by da Rosa et al. (2020) that showed enhanced performance. The phenological scale used to determine the application stage was that of Fehr and Caviness (1977).

\section{Procedure}

The experiment was conducted in a no-tillage system on wheat (Triticum aestivum L.) crop remains. The fertilisation was carried out with $6 \mathrm{~kg} \mathrm{ha}^{-1}$ of $\mathrm{N}, 60 \mathrm{~kg} \mathrm{ha}^{-1}$ of $\mathrm{P}_{2} \mathrm{O}_{5}$ and 60 $\mathrm{kg} \mathrm{ha}^{-1}$ of $\mathrm{K}_{2} \mathrm{O}$. Seeds were inoculated with Bradyrhizobium japonicum and treated with insecticides (imidacloprid and thiodicarb) and fungicides (carbendazim and thiram). The sowing density was 20 seeds per square metre, as recommended (TMG, Tropical Melhoramento \& Genética). Treatments with population reduction were subjected to manual thinning after emergence. The other methods of crop management were carried out according to technical recommendations (Marcos et al., 2018).

Each experimental plot was composed of five sowing rows, each one $7 \mathrm{~m}$ long and spaced $0.45 \mathrm{~m}$ from each other. The first and fifth rows were used as borders, $2 \mathrm{~m}$ at the end of each plot was used for destructive evaluation, and the remaining $5 \mathrm{~m}$ was used to estimate the final yield at harvest. In addition to the protective borders against drift, the plots were a considerable distance from each other.

Lactofen application was performed using a $\mathrm{CO}_{2}$-pressurised knapsack sprayer (Herbicat, HB PES 003) equipped with a boom with four Teejet ${ }^{\oplus}$ TT110015 flat-fan spray tips, which produced medium-sized droplets (Asae, 2000). The spray tips were spaced $0.5 \mathrm{~m}$ apart from each other, and the equipment was set to a constant service pressure and spraying volume of $150 \mathrm{~L} \mathrm{ha}^{-1}$. The travel speed was $\sim 5 \mathrm{Km} \mathrm{h}$ 1

\section{Plant growth and development}

Plant height $(\mathrm{cm})$ evaluations were carried out at two phenological stages of the crop (R1 and R5.2). Ten plants were randomly selected at each plot and measured using a measuring tape from the plant base to the last node with a fully expanded trifoliolate leaf. Ten plants at phenological stage R5.2 were collected in sequence in the planting row to determine the following variables: leaf area index (LAI), the total number of nodes per plant, number of branches (branches with at least one node), stem diameter $(\mathrm{mm})$ between the first and second node at the plant base and internode length $(\mathrm{cm})$ between the third and fourth and sixth and seventh nodes. The LAI was measured using a leafarea integrator (LI-COR-31000C). The value obtained for ten plants was extrapolated to $1 \mathrm{~m}^{2}$ of soil. The counting of the number of nodes per plant did not consider the first node of the plant base.

\section{Plant protection-product droplet deposition}

Droplet deposition was evaluated by applying a spray solution composed of water alone using a mechanised sprayer (Jacto, M12 CONDOR 600) equipped with Teejet TT110015 flat-fan spray tips, which produced medium-sized 
droplets (Asae, 2000). The working speed was $6.0 \mathrm{~km} \mathrm{~h}^{-1}$ to obtain a sprayed volume of $150 \mathrm{~L} \mathrm{ha}{ }^{-1}$. Plants were at phenological stage R2 (full flowering) during application. Water-sensitive cards $(7.5 \times 2.5 \mathrm{~cm}$, developed by Syngenta) were placed on each plant layer (upper, middle and lower) at the time of spraying for each treatment and affixed using an iron rod attached to the ground in the crop interrow. The purpose of this water-sensitive paper was to evaluate the deposition of droplets of phytosanitary spray solution on the layers (Nascimento et al., 2013). After application, these papers were stored in paper envelopes to ascertain the percentage of covered area and the number of droplets per $\mathrm{cm}^{2}$. The reading of water-sensitive papers and the subsequent evaluation of the data was carried out using the Dropscope software.

\section{Intercepted photosynthetically active radiation}

The evaluation of the interception of the photosynthetically active solar radiation (PAR) was carried out from phenological stage R1 in the upper and lower strata of the crop canopy. PAR interception was interpreted as follows: the total PAR intercepted in the upper layer minus that intercepted in the middle layer provided the value for the upper layer, and this result minus the interception of the lower layer provided the reading of the lower stratum. These readings were performed using a radiation bar (Ceptômetro AccuPAR, LP-80), which was placed between the crop interrows on different layers. The reading was performed from phenological stage R1 for ten days, always at 12 p.m. and with a completely clear sky (Moojen et al., 2012). The results were expressed in $\mu \mathrm{mol} \cdot \mathrm{m}^{-2} \cdot \mathrm{s}^{-1}$.

\section{Grain yield components}

The variables related to yield components were estimated at the grain maturity stage on 10 randomly selected plants per plot, stratified according to layers (upper, middle and lower) by measuring plant height and dividing it into three equal parts. The evaluated variables were the number and weight of grains per third (corrected for $13 \%$ moisture).

Grain yield $\left(\mathrm{kg} \mathrm{ha}^{-1}\right)$ was determined by harvesting the plot using a plot harvester (SEMINA, M1400). Subsequently, samples were weighed, corrected for $13 \%$ moisture and transformed into grain yield per hectare. The thousand-grain weight was measured at harvest by collecting one sample, counting 250 grains and adjusting it to $13 \%$ moisture.

\section{Statistical analysis}

Analysis of variance (ANOVA) was carried out on the data, and the means were compared by the Duncan test at a $5 \%$ probability of error using the statistical program CoStat (Costa and Castoldi, 2009).

\section{Conclusion}

In this study, the reduction in the plant density decreased the grain yield, showing that the plant population should be maintained as recommended. Furthermore, lactofen application in the first year did not improve yields as much as it did in the following year. Therefore, a strong environmental interaction is possibly influencing the results. It is clear that the lactofen growth regulator modifies the architecture of plants and increases the yield, which was aided by a period of subsequent rainfall, as shown in Fig. 1B. Accordingly, further in-depth studies could provide a set of standard practices, along with information on whether to apply lactofen in soybean crops.

\section{Acknowledgements}

The authors are grateful to Coordenação de Aperfeiçoamento de Pessoal de Nível Superior (CAPES) for financial support, PNPD/CAPES for the scholarship of Andréia Caverzan and Prosup/CAPES scholarship of da Willian Pelisser da Rosa.

\section{References}

ASAE. American Society of Agricultural Engineering (2000) In: Spray nozzle classification by droplet spectra. St. Joseph, S572, p. 389-91.

Bahry CA, Venske E, Nardino M, Zimmer PD, Souza VQ, Caron BO (2013) Desempenho agronômico da soja em função da desfolha em diferentes estádios vegetativos. Tecnologia e Ciência Agropecuária 7: 19-24.

Bellaloui N, Mengistu A, Walker ER, Young LD (2014) Soybean seed composition as affected by seeding rates and row spacing. Crop Science. 54: 1782-1795.

Buzzello GL, Michelangelo MT, Marchese JA, Xavier E, Miotto Junior E, Patel F, Debastiani F (2013) Action of auxin inhibitors on growth and grain yield of soybean. Revista Ceres. 6: 621-628.

Campos MF, Ono EO, Boaro CSF, Rodrigues JD (2008) Growth analysis of soybean plants treated with plant growth regulators. Revista Biotemas. 21: 53-63

Campos MF, Ono EO, Rodrigues JD (2009) Effect of plant growth regulators on the development of soybean plants. Revista Ceres. 56: 74-79.

Cato SC, Castro PRC (2006) Height reduction in soybean plants caused by 2,3,5-triiodobenzoic acid. Ciência Rural. 36: 981-984.

Chavarria G, Caverzan A, Müller M, Rakocevic M (2017) Soybean architecture plants: From solar interception to crop protection. In: M. Kasai, editor, Soybean: The basis of yield, biomass and productivity, Intech, Rijeka, Croatia. p. 15-33.

Cheng J, Yuan C, Graham TL (2011) Potential defense-related prenylated isoflavones in lactofen-induced soybean. Phytochemistry. 72: 875-881.

Costa C, Castoldi FL (2009) CoStat: um programa para quem pensa que não gosta de estatística. 1. ed. Passo Fundo: UPF Editora, v. 1. 384p

Dario GJA, Martin TN, Dourado D, Manfron PA, Bonnecarrère RAG, Crespo PEN (2005) Influence of the crop regulator use in the growth of soybean. Revista FZVA. 12: 63-70.

Embrapa Trigo (2018) Laboratory of applied meteorology to agriculture of Embrapa Trigo. Embrapa. http://www.cnpt. embrapa.br/pesquisa/agromet/app/principal/ (accessed 20 Apr. 2018).

Embrapa Trigo (2019). Laboratory of applied meteorology to agriculture of Embrapa Trigo. Embrapa. http://www.cnpt. embrapa.br/pesquisa/agromet/app/principal/ (accessed 30 May. 2019).

Fehr WR, Caviness CE (1977) Stages of soybean development. Cooperative Extension Service, Agriculture and Home Economics Experiment Station, lowa State University, Ames, IA.

Ferreira AS, Balbinot Junior AA, Werner F, Franchini JC, Zucareli C (2018) Soybean agronomic performance in response to seeding rate and phosphate and potassium fertilization. Revista Brasileira de Engenharia Agrícola e Ambiental. 1: 151-157. 
Gallon M, Buzzello GL, Trezzi MM, Diesel F, Silva HL (2016) Action of PROTOX inhibitors herbicide on the development, lodging and yield of soybean. Revista Brasileira de Herbicidas. 15: 232-240

Graham MY (2005) The diphenylether herbicide lactofen induces cell death and expression of defense-related genes in soybean. Plant Physiology. 139: 1784-1794.

Gregg GL, Orlowski JM, Lee CD (2015) Input-based stress management fails to increase soybean yield in Kentucky. Crop Forage Turfgrass Manager. 1.

Heiffing LS, Câmara GMS, Marques LA, Pedroso DB, Piedade SMS (2006) Closed canopy and leaf area index of soybean in different space arrangements. Bragantia. 65: 285-295.

Huzar-Novakowiski J, Paul PA, Dorrance AE (2017) Host Resistance and Chemical Control for Management of Sclerotinia Stem Rot of Soybean in Ohio. Phytopathology. 107: 937-949.

Liu X, Jin J, Wang G, Herbert SJ (2008) Soybean yield physiology and development of high-yielding practices in Northeast China. Field Crops Research. 105: 157-171.

Liu B, Liu X, Wang X, Jin J, Herbert SJ, Hashemi M (2010) Responses of soybean yield and yield components to light enrichment and planting density. International Journal of Plant Production. 4: 1-9.

MangialardiJ.P, Orlowski JM, Lawrence BH,Bond JA, Golden BR, Catchot A, Peeples JD, Eubank TW (2016) Growth regulation with lactofen does not affect seed yield of irrigated soybean. Agronomy Journal. 1081112-1115.

Marcos C, João LFP, Alencar PR, Cinei TR, Leticia SHH, Rodrigo D, Rodrigo P (2018) Indicações Técnicas para a Cultura da Soja no Rio Grande do Sul e em Santa Catarina, safras 2018/2019 e 2019/2020. 42. ed. Três de Maio - RS, Setrem, 107p.

Martins MC, Câmara GMS, Peixoto CP, Marchiori LFS, Leonardo V, Mattiazzi P (1999) Sowing date, planting density and vegetative performance of soybean cultivars. Scientia Agricola. 56: 851-858.

Menegaz W, Suárez-Castellanos Cl, Meneghello GE, Bohn A, de Oliveira AL, Schuch LOB (2018) Multiplication of soybean seeds at low seeding rates. Agrociencia Uruguay. 22: $45-52$
Moojen TMB, Cavalcante RBL, Mendes CAB (2012) Solar radiation evaluation based on cloudiness data. Geografia. 21: 41-55.

Müller M, Rakocevic M, Caverzan A, Chavarria G (2017) Grain yield differences of soybean cultivars due to solar radiation interception. American Journal of Plant Sciences. 8: 2795-2810.

Müller M, Rakocevic M, Caverzan A, Boller W, Chavarria G (2018) Architectural characteristics and heliotropism may improve spray droplet deposition in the middle and low canopy layers in soybean. Crop Science. 58: 2029-2041.

Nascimento AB, Oliveira GM, Fonseca ICB, Saab OJGA, Canteri MG (2013) Determination of the samples required of water-sensitive paper in experiments related spray technology. Semina, Ciências Agrárias. 34: 687-2696.

Orlowski JM, Gregg GL, Lee CD, Serson WR (2016a) Earlyseason lactofen application fails to increase soybean yield under weed-free conditions. Agronomy Journal. 108: 1552-1560.

Orlowski JM, Gregg GL, Lee CD (2016b) Early-season lactofen application has limited effect on soybean branch and mainstem yield components. Crop Science. 56: 1-7.

da Rosa WP, Caverzan A, Chavarria G (2020) Grain productive efficiency of soybean plants under lactofen application. Plant Sci Today. 7: 288-295.

Souza CA, Figueiredo BP, Coelho CMM, Casa RT, Sangoi L (2013) Plant architecture and productivity of soybean affected by plant growth retardants. Bioscience Journal. 29: 634-643

Souza RT, Constantin J, Velini ED, Montorio GA, Maciel CDG (2002) Selectivity of latifolicide herbicide combinations with lactofen for the soybean crop. Scientia Agricola. 59, 99-106.

Streck EV, Kampf N, Dalmolin RSD, Klamt E, Nascimento PC, Schneider P. et al. (2008) Solos do Rio Grande do Sul. 2nd ed. Empresa de Assistência Técnica e Extensão Rural do Rio Grande do Sul, Porto Alegre, Brasil.

Wichert RA, Talbert RE (1993) Soybean (Glycine max (L.) Merrill) response to lactofen. Weed Science. 41:23-26. 